\title{
Delayed Non-word Repetition according to Rehearsal Conditions in 6- to 7-Year-Old Children
}

\author{
Seok-Jung Lee ${ }^{\mathrm{a}}$, Ji-Wan Ha ${ }^{\mathrm{a}, \mathrm{b}, \mathrm{c}}$, Min-Mo Koo ${ }^{\mathrm{d}}$, Yu Mi Hwang ${ }^{\mathrm{c}, \mathrm{e}}$, Sung-Bom Pyun ${ }^{\mathrm{f}, \mathrm{g}}$ \\ ${ }^{a}$ Department of Speech \& Language Pathology, Graduate School of Rehabilitation Science, Daegu University, Gyeongsan, Korea \\ ${ }^{b}$ Department of Speech Pathology, Daegu University, Gyeongsan, Korea \\ 'International Institute of Rehabilitation Science, Daegu University, Gyeongsan, Korea \\ ${ }^{d}$ Biomedical Research Center, Korea University Anam Hospital, Seoul, Korea \\ ${ }^{e}$ Research Institute for Language \& Information, Korea University, Seoul, Korea \\ ${ }^{f}$ Department of Physical Medicine and Rehabilitation, Korea University College of Medicine, Seoul, Korea \\ ${ }^{8}$ Brain Convergence Research Center, Korea University Anam Hospital, Seoul, Korea
}

Correspondence: Ji-Wan Ha, PhD

Department of Speech Pathology, Daegu

University, 201 Daegudae-ro, Jillyang-eup,

Gyeongsan 38453, Korea

Tel: $+82-53-850-4327$

Fax: +82-53-850-4329

E-mail: jw-ha@daegu.ac.kr

Received: January 5, 2016

Revised: February 12, 2016

Accepted: February 17, 2016

This work was supported by the National Research Foundation of Korea Grant funded by the Korean Government (NRF-2013S1A3A2043454).

This research was supported by the Daegu University Research Scholarship Grants.
Objectives: Among memory strategies, the one most closely related to short-term memory is rehearsal strategy. This research aims to study the influences of rehearsal conditions on the phonological short-term memory of typically developing children. Methods: Forty children age 6 to 7 performed delayed non-word repetition (dNWR) tasks according to rehearsal conditions (vocal rehearsal, subvocal rehearsal, rehearsal suppression). The accuracy and error types of three dNWR tasks were analyzed. The relationships among speech perception, digit forward, expressive vocabulary, and dNWR performances by each rehearsal condition were examined. Results: The 6-year-old group showed higher performances in the order of vocal rehearsal, subvocal rehearsal, and rehearsal suppression, while the 7-year-old group showed no significant difference between vocal rehearsal subvocal rehearsal, showing a significance only between those two conditions and rehearsal suppression. In the 6-year-old group, a'no response' was the most abundant error type in rehearsal suppression, but 'phoneme substitution' increased in rehearsal conditions. In the 7-yearold age group 'phoneme substitution' appeared most frequently of all error conditions. The variables with the most predictive power were digit forward in vocal rehearsal, speech perception in subvocal rehearsal, and speech perception and expressive vocabulary in rehearsal suppression, respectively. Conclusion: dNWR performances with rehearsals showed better results than those without rehearsals. Also, there was a difference according to age between vocal rehearsal and subvocal rehearsal.

Keywords: Delayed non-word repetition task, Vocal rehearsal, Subvocal rehearsal, Rehearsal suppression, Phonological short-term memory
아동은 주로 보고 듣는 것으로 정보를 접하고 기억한다. 이러한 기억이 장기기억 속에 형성되려면 명시적이든 암묵적이든 반복적 경험이 필요한데, '시연(rehearsal)' 또한 광의의 의미에서 일종의 반 복적 경험으로 볼 수 있다. 시연이란 제시된 항목들을 반복하여 능 동적으로 암송하는 것을 일컫는다(Moon, 1994). 시연의 일차적인 기능은 음운단기기억을 촉진하는 것으로, 음운단기기억에 있는 정 보들은 시연을 통해 유지되고 재구조화될 때 비로소 장기기억까지 연장될 수 있다(Cohen \& Heath, 1990; Salamé \& Baddeley, 1982).
시연과 관련된 이론 또는 모델에는 이중기억 이론(dual-memory theory) (Atkinson \& Shiffrin, 1968), 다중기억 모델(multi process memory model) (Ellis, 1970), 작업기억 모델(working memory model) (Baddeley, 1986), 기억책략이론(Papalia, Olds, \& Feldman, 2002) 등이 있다.

우선 이중기억 이론을 살펴보면, Atkinson과 Shiffrin (1968)은 기억을 감각기억, 단기기억, 장기기억으로 이루어진 3 개의 기억 저 장형태와 주의집중, 시연, 부호화(encoding), 인출로 이루어진 4개 
의 통제과정(control process)으로 분류하였다. 여기에서 시연은 주 의집중과 더불어 단기기억과 직접적으로 관련된 통제과정으로 설 명된다. 외부로부터 감각기억을 통해 들어오는 정보는 주의집중을 통해 단기기억으로 전달되는데, 이때 주의집중의 정도에 따라 전달 되는 정보의 양이 달라진다. 그러나 정보가 단기기억에 도달되면 그 정보는 곧 사라지기 때문에, 능동적인 시연 과정을 통해서만 그 정보가 유지될 수 있다. 이와 비슷한 시기에 Ellis (1970)는 다중기억 모델을 제시하였다. 1 차기억(primary memory), 2 차기억(secondary memory), 3 차기억(tertiary memory)의 3 단계 다중기억 시스템에 서 시연전략은 모든 정보처리과정에 사용된다. 주의가 집중된 상태 에서 언어적 정보는 외부자극으로부터 1차기억으로 들어오는데, 1 차기억 장치의 수용능력은 극히 제한적이기 때문에 새로운 정보는 불완전한 상태를 이룬다. 따라서 2-3초 이상 경과하면 1차기억 내 의 정보는 영원히 상실되고 만다. 이것을 막기 위해 시연전략이 작 동하게 된다. 여기에서 시연이란 즉각적이든, 지연적이든, 묵시적이 든, 의식적이든, 무의식적이든 언어적 항목(verbal item)의 재생을 의미한다. 시연전략은 1 차기억에서부터 2 차기억과 3 차기억으로 정 보를 이동시키는 메커니즘으로, 이것이 존재하기 때문에 정보 보유 (retention)가 가능하다(Won, 1998).

시연과 관련된 또 다른 모델로는 국내외 연구들에 가장 폭넓게 적용되고 있는 Baddeley (1986)의 작업기억 모델을 들 수 있다. 작업 기억 모델에서는 중앙집행기(central executive), 음운루프(phonological loop), 시공간잡기장(visuo-spatial scratch), 일화적 완충기 (episodic buffer) 등이 그 하위요소를 이루고 있으며, 이 요소들은 서로 능동적으로 상호작용한다(Baddeley, 2000). 이 가운데 시연과 가장 관련이 깊은 하위요소는 음운루프이다. 음운루프의 시연과 정과 음운저장소는 언어습득에 필수적인 요소로, 어휘습득 과정 에 적극 활용된다(Baddeley, Gathercole \& Papagno, 1998; Cleary, Pisoni, \& Geers, 2001; Paik, Ahn, Seo, \& Shin, 2007). 시연과정을 통한 학습은 시연을 얼마나 많이 하느냐에 따라 정보가 단기기억 에 얼마나 오래 지속될 수 있는지에 영향을 미친다. 때문에 시연을 더 많이 할수록 더 많은 정보가 단기기억에 저장될 수 있다(Moon, 1994).

마지막으로 시연에 관한 것은 기억책략(memory strategy)에 대 한 발달연구에서도 찾아볼 수 있다. 기억책략은 시연책략, 조직화 책략, 정교화책략으로 구분될 수 있는데(Papalia et al., 2002), '시연 책략'은 기억해야 할 항목들을 의식적으로 반복해서 말함으로써 정보를 유지하려는 노력을 말한다. '조직화책략'은 항목들을 범주 나 단위로 분류하는 과정을 통하여, 그리고 '정교화책략'은 항목들 을 의미 있는 심상이나 이야기로 묶는 작업을 통하여, 정보를 좀 더
기억하기 쉽게 만드는 방법을 의미한다(Papalia et al., 2002). 기억책 략의 발달 과정에서 시연책략은 대략 6-7세경에 나타나고, 조직화 책략이 그 후에, 그리고 정교화책략이 가장 나중에 발달한다(Vasta, Haith, \& Miller, 1992). 기억 능력은 일반적으로 연령이 높을수 록 발달하는데, 이는 아동의 연령이 높아짐에 따라 당면한 상황에 서 과제의 목적에 부합하는 기억책략을 효과적으로 선택하고 적용 하는 능력 또한 발달하기 때문이다(Bjorklund, Miller, Coyle, \& Slawinski, 1997; DeLoache, Cassidy, \& Brown, 1985). 이와 관련하 여 Park (2007)은 5세, 7세, 9세 일반아동을 대상으로 자발적 기억 책략을 연구하였다. 외현적 시연, 내현적 시연, 자기점검, 범주화책 략 가운데 외현적 시연이 사용빈도가 가장 높고, 그 다음 내현적 시 연이 빈번하다고 보고하였다. 이어서 자발적 기억책략의 유형에 따 라 회상 수준에 차이를 보이는지 알아본 결과, 사용빈도가 높았던 내현적 시연의 경우 회상 수준에서는 오히려 가장 낮은 수행력을 보였다고 보고하였다. 이러한 결과는 학령기 전후의 아동들이 가 장 빈번하게 사용하는 기억책략은 외현적 시연과 내현적 시연이지 만, 그것이 기억에 미치는 영향에는 차이가 있을 수 있다는 것을 시 사한다.

외현적 시연은 소리를 내면서 되풀이하는 것을, 내현적 시연은 소리를 내지 않고 마음 속으로 되뇌는 것을 말한다. Baddeley (1986) 는 음운루프에서 일어나는 시연을 '언어적 정보 처리를 위해 소리 없이 조음시연(subvocal articulation rehearsal)하는 방법’이라고 설 명하였다. 시연과정을 외현적과 내현적으로 명확하게 구분하지는 않았지만, Baddeley의 이론에서 시연과정은 내현적 시연에 해당하 는 듯하다. 반면 언어중재 이론(Luria, 1961; Vygotsky, 1962)에서는 외현적 언어와 내현적 언어를 구분하고, 이 둘이 행동통제에 미치 는 영향은 확연하게 다른 것으로 주장한다. 즉, 언어중재 이론에서 외현적 언어와 내현적 언어에 따른 행동통제 기제의 차이는 기억수 행에서 외현적 시연과 내현적 시연에 차이가 있을 가능성을 의미한 다고 할 수 있다. 그럼에도 불구하고 아동발달 분야에서 시연에 대한 많은 국내외 연구들이 기억과 관련하여 주로 외현적 시연만을 다 루고 있거나(Alt \& Spaulding, 2011; Kim, 1988; Kim, 1997; Loomes, Rasmussen, Pei, Manji, \& Andrew, 2007), 또는 외현적 시연과 내현 적 시연을 구분하지 않은 채 실험을 실시하여 왔다(Kim, 2012; Oxley \& Norris, 2000). 최근에서야 외현적 조음억제와 내현적 조음억 제에 차이가 있다는 연구결과(Chung, 2012; Chung \& Kim, 2010) 등이 보고되면서, 외현적 시연과 내현적 시연을 구분하여 그 둘의 차이가 음운단기기억력에 미치는 영향에 대해 알아볼 필요성이 제 기되었다. 상대적으로 더 많은 연구가 이루어진 외현적 시연은, 아 직 그 효과가 명확하게 밝혀지지 않은 내현적 시연보다 분명 아동 
의 음운단기기억 향상에 기여하는 바가 있는 것으로 여겨진다. 그 러나 언어습득과정에서 내현적 시연 또한 매우 빈번하게 활용되고 있어(Greene, 1987; Park, 2007), 내현적 시연이 기억에 미치는 영향 에 대한 연구 또한 보다 활발하게 이루어져야 할 필요가 있다. 무엇 보다 이제까지 시연에 관한 많은 연구들에서 그 결과가 외현적 시 연으로 인한 것인지, 내현적 시연으로 인한 것인지, 또는 두 유형의 시연활동이 복합적으로 작용한 것인지에 대한 명확한 설명은 어려 운 실정이다. 따라서 음운단기기억에 미치는 시연의 영향을 좀 더 심층적으로 연구하기 위해서는, 외현적 시연과 내현적 시연을 구분 하여 과연 어떠한 시연책략이 기억 향상에 보다 결정적인 기여를 하는지에 대해 연구할 필요가 있다.

본 연구에서는 일반아동을 대상으로 외현적 시연, 내현적 시연, 시연 억제의 상이한 시연조건들이 음운단기기억에 어떠한 영향을 미치는지 알아보고자 하였다. 음운단기기억을 측정하는 과제에는 숫자따라말하기, 낱말따라말하기, 문장따라말하기, 비단어따라말 하기 등이 있는데, 이 가운데 비단어따라말하기가 가장 민감하게 음운단기기억을 측정할 수 있고 언어와의 상관성 또한 높다고 보고 되었다(Baddeley et al., 1998; Gathercole, Willis, \& Baddeley, 1991). 또한 음운단기기억 과제를 즉각 단기기억 과제(immediate shortterm task)와 지연 단기기억 과제(delayed short-term task)로도 구 분할 수 있는데(Brookshire, 2007), 전자는 주어진 자극을 바로 회 상하는 것이고 후자는 일정한 시간 간격을 두고 나서 회상하는 것 이다. 비단어따라말하기를 즉각 과제와 지연 과제로 구분한다면, 제시된 비단어를 바로 따라말하게 하는 것을 '즉각 비단어따라말 하기(immediate non-word repetition task)', 얼마의 시간이 경과한 후 따라말하게 하는 것을 '지연 비단어따라말하기(delayed nonword repetition task)'라고 할 수 있다. 이에 대한 선행연구를 살펴 보면 Kim, Choi와 $\mathrm{Ha}$ (2015)의 연구에서는 일반아동과 조음·음운 장애 아동의 경우 즉각 비단어따라말하기보다 지연 비단어따라말 하기에서 반응시간이 유의하게 느렸고, Lee (2015)의 연구에서는 정상 성인에서 즉각 비단어따라말하기보다 지연 비단어따라말하 기에서 더 낮은 수행력이 보고되었다. 이러한 연구결과들에 근거할 때 아동과 성인 모두에서 즉각 비단어따라말하기보다 지연 비단어 따라말하기가 더욱 난이도가 높은 과제로 여겨지며, 따라서 지연 비단어따라말하기 과제를 성공시키기 위해서는 별도의 노력이 필 요한 것으로 보인다. 이와 관련하여 Brookshire (2007)는 시연의 중 요성을 강조하였다. 일정한 시간이 경과한 후 자극어를 회상하여 야 하는 지연 단기기억 과제는 즉각 단기기억 과제보다 시연책략이 더욱 요구되는 과제라는 것이다. 다시 말해 지연 단기기억 과제는 주어진 자극을 좀 더 오랫동안 보유하여야 하기 때문에, 과제를 성
공적으로 수행하기 위해서는 의식적이든 무의식적이든 시연과정 을 좀 더 적극 활용하여야한다.

이와 같은 이유로 본 연구에서는 시연을 포함한 음운단기기억 능 력을 평가하는 방법으로 지연 비단어따라말하기 과제를 이용하 여, 그 정확도와 오류를 분석하였다. 앞에서 언급하였듯이 지연 비 단어따라말하기 과제는 청각적으로 제시된 비단어 자극어를 일정 시간 경과 후 다시 말하는 것으로, 과제 수행 시 요구되는 단기기억 은 자극에 대한 수동적 저장공간이라기보다 시연활동을 통한 능 동적인 보유능력이다. 그러나 일정 시간이 지나치게 길어질 경우 대 상자들은 자극어를 오랫동안 계속하여 유지하기 위해 정보들을 '보유'하기보다는 '조작'하려 할 것이며, 이와 같은 과정을 통해 대 상자의 수행력이 단기기억이 아닌 작업기억의 개념으로 확대될 가 능성이 있다. 때문에 연구자들은 과제 수행 시 요구되는 능력이 대 상자들의 단기기억의 범위를 넘지 않도록, 또는 실험 시 주의력이 흐트러지는 것을 막기 위해 여러 차례의 예비실험을 통하여 지연 시간을 8초로 제한하였다. 그리고 발달과정상 6-7세경 시연책략이 나타난다는 선행연구(Papalia et al., 2002)에 근거하여, 본 연구의 대상자를 6,7 세 일반아동으로 한정하였다. 더불어 말지각 능력, 단 기기억력, 어휘량과 같은 기저요인들이 비단어따라말하기 과제 수 행에 영향을 미칠 수 있다는 선행연구(Kim \& Ha, 2014)에 근거하 여, 본 연구의 실험과제 수행력과 자음변별 능력, 숫자 바로따라하 기 능력, 표현어휘량의 관계를 알아보았다.

이와 같은 본 연구의 연구질문을 정리해 보면 다음과 같다. 첫째, 집단(6세 vs. 7세) 간 시연조건(외현적 시연 vs. 내현적 시연 vs. 시연 억제)에 따른 지연 비단어따라말하기 정확도에 유의한 차이가 있 는가? 둘째, 집단(6세 vs. 7세) 간 시연조건(외현적 시연 vs. 내현적 시 연 vs. 시연 억제)에 따른 지연 비단어따라말하기 오류유형의 비율 에 차이가 있는가? 셋째, 말지각 능력, 단기기억 능력, 표현어휘량과 각 시연조건(외현적 시연 vs. 내현적 시연 vs. 시연 억제)에 따른 지 연 비단어따라말하기 정확도의 상관관계와 그 정확도를 유의하게 예측하는 변수는 무엇인가? 시연에 관한 선행연구들(Park, 2007; Vasta et al., 1992)에 근거할 때, 마음속으로만 되뇌이는 내현적 시 연보다 청각적 피드백이 동반되는 외현적 시연이 대상아동들의 음 운단기기억력을 보다 향상시킬 것으로 예상된다. 그러나 이러한 결 과가 두 연령집단에서 동일하게 나타날지, 그리고 시연조건의 차이 가 오류유형에도 영향을 미칠지에 대해서는 예측이 어렵다. 또한 선행연구(Kim \& Ha, 2014)에서 말지각 능력, 단기기억 능력, 표현 어휘량이 모두 비단어따말하기 과제 수행과 관련이 있는 요인들로 보고되었지만(Kim \& Ha, 2014), 이것은 즉각 비단어따라말하기에 대한 연구결과로 시연조건을 달리한 지연 비단어따라말하기의 경 
우에는 어떠한 결과가 초래될 지 알 수 없다. 따라서 본 연구의 결과 는 음운단기기억력을 향상시키거나 음운단기기억을 통한 어휘습 득을 유도할 때 각 연령대에서 어떠한 시연조건이 가장 활용도가 높을지, 더 나아가 시연조건별 음운단기기억에 영향을 미치는 기저 요인은 무엇인지에 대해 시사하는 바가 있을 것이다.

\section{연구방법}

\section{연구대상}

본 연구는 6,7 세 일반아동 각 20 명씩 총 40 명을 대상으로 하였 다. 대상자의 선정기준은 다음과 같다. 첫째, 부모와 교사 보고에 의 해 감각적, 신경학적, 신체적 결함이 없고 인지, 언어적 문제가 없는 아동, 둘째, 수용·표현어휘력검사(REVT; Kim, Hong, Kim, Jang, \& Lee, 2009) 결과 수용·표현 어휘능력이 -1 SD 이상의 성취를 보이 는 아동, 셋째, 우리말 조음음운평가(U-TAP; Kim \& Shin, 2004) 결 과 단어 수준의 자음정확도가 $-1 \mathrm{SD}$ 이상의 성취를 보이는 아동들 로 하였다. 대상자들의 평균연령은 84 (6.91)개월이었고-6세 집단 77.9 (3.13)개월, 7세 집단 90.2 (3.11)개월-성별은 남아 21명, 여아 19 명이었다. 두 연령집단 간 연령 차이는 유의하였고 $(p<.001)$, 성별 차이는 유의하지 않았다( $p>$.05). 그리고 두 집단 간 수용어휘력과 표현어휘력의 차이는 유의하였으나 $(p<.001)$, 자음정확도는 모든 대상자들이 $100 \%$ 로 집단 간 차이가 유의하지 않았다( $p>.05)$.

\section{실험 과제 제작}

비단어 자극어 선정

비단어따라말하기의 수행력은 본 연구의 실험 변수인 말지각 능 력, 단기기억 능력, 어휘량과 같은 대상자의 특성뿐 아니라, 과제를 구성하는 말소리의 특성에도 영향을 받는다(Kim \& Ha, 2014). 그 중 단어유사성이 높은 비단어는 그렇지 않은 비단어보다 더 좋은 수행력을 초래한다는 결과가 여러 연구들에서 보고된 바 있다(Edwards, Beckman, \& Munson, 2004; Munson, Edwards, \& Beckman, 2005). 따라서 본 연구에서는 단어유사성이 낮은 비단어만으로 과 제를 구성하기 위하여, 그 자체로는 의미가 없어 어휘저장소에 단 어로 저장되어 있지 않은 1 음절들을 조합하여 비단어 항목을 만들 고자 하였다. 그러나 한국어의 경우 의미가 없는 1 음절을 찾는 것 은 쉽지 않아, 대명사, 수사, 의존명사의 의미를 가지는 1 음절어는 허용하고 보통명사의 의미를 가지는 1 음절어는 제외하도록 하였다.

이를 위하여 두 종류의 말뭉치 자료(Jo, 2002; Kim \& Kang, 1997) 를 참고하였다. 우선 Kim과 Kang (1997)의 한글 사용빈도 분석을 이용하여 단음절을 모두 추출하였다. 그러고 나서 Jo (2002)의 단
음절 명사 표제어에 근거하여, 구체적 명사로서 의미를 가지는 단 음절 단어와 한국어에서 쓰이지 않는 비사용 음절을 제외하였다. 이와 같은 과정을 통하여 1,771 개의 음절이 추출되었다. 추출된 음 절은 홀로 단어로서 기능하지 못하나(대명사, 수사, 의존명사로는 가능함) 한국어 단어의 일부로는 사용되는 음절들이다. 모음은 7

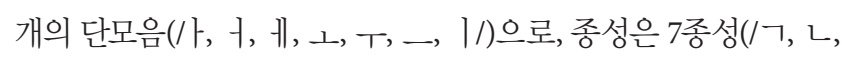
ᄃ, ㄹ, ㅁ, 비, ㅇ/)으로 국한하였다. 조음능력의 미성숙으로 인한 과제수행의 어려움을 배제하기 위하여 초성에서 유음, 치경마찰 음, 파찰음을 제외하고자 하였으나, 그럴 경우 남는 음절이 너무 제 한적이어서 유음은 포함시켰다. 이렇게 하여 1,771 개의 예비 음절 에서 최종적으로 219 개의 음절만이 남았다.

최종 219 개의 단음절에 대하여 난수표를 이용한 무선 조합을 실 시하여, 3음절부터 5음절로 구성된 음절조합 항목들을 만들었다. 비단어따라말하기 과제 시 3음절 이상(Dollaghan \& Campbell, 1998), 5음절 이하(Hwang, 2015)에서 대상 아동들의 특성이 수행 력에 영향을 줄 수 있다는 선행연구에 근거하여, 본 연구의 비단어 음절수를 $3,4,5$ 음절로 한정하였다. 발음의 용의성을 위하여 첫 음 절은 $\mathrm{CV}$ 구조, 마지막 음절은 $\mathrm{CVC}$ 의 구조로 이루어진 조합으로 구성하였다(Dollaghan \& Campbell, 1998). 각 음절에 종성이 연속 적으로 포함되어 발음하기 쉽지 않은 음절조합을 제외하여, $3,4,5$ 음절 각 20 항목씩 총 60 항목을 예비항목으로 선정하였다. 음절화, 경음화, 공명음화 등의 음운변동규칙이 적용되는 음절조합에 대해 서는 음운변동규칙을 적용한 후 재기록하였다.

본 실험에 들어가기에 앞서 언어치료학과 대학원생 5 명을 대상 으로 총 60 개의 예비항목으로 지연(10초 후) 비단어따라말하기 예 비실험을 실시하였다. 예비실험 참여자들이 상대적으로 오반응을 많이 보인 항목들을 각 음절별로 5 개씩 제외하여, $3,4,5$ 음절 각 15 항목씩으로 이루어진 총 45 개의 최종 비단어 목록을 선정하였다 (Appendix 1). 100만 음절 말뭉치 자료(Kim \& Kang, 1997)에 근거 하였을 때, 항목들의 평균 음절빈도는 3음절 892.45 (54.03), 4음절 665.35 (99.62), 5음절 833.74 (75.71)였다. 최종 비단어 목록에 대해 언어치료학과 학부생 130 명을 대상으로 단어유사성 정도를 측정 하였다. 단어유사성은 5 점 척도(1점: 단어와 매우 유사하지 않음, 5 점: 단어와 매우 유사함)의 평정법을 사용하였다. 모든 비단어 항목 이 3점 이하(평균 2.04 점)의 점수를 획득하였다. 따라서 본 연구의 실험 자극어는 음절빈도는 높고 단어유사성은 낮은 비단어들로 이 루어졌다고 할수 있다.

전산화된 지연 비단어따라말하기 과제 제작

전문 아나운서가 방음실에서 45 개의 비단어 자극어를 녹음하였 
다. 성인의 경우 10 초에서 30 초 정도 시간이 경과하면 비단어따라 말하기의 수행력 저하가 나타난다는 보고(Brookshire, 2007)에 근 거하여, 최대 지연시간을 10 초로 한정한 후 6 세와 7 세 일반 아동 총 3 명을 대상으로 예비실험을 실시하였다. 10 초 내에서 지연시간을 달리하여 여러 차례 예비실험을 실시한 결과, 지연 시간이 8 초를 초 과하면 아동들의 주의력이 흐트러지는 것으로 판단되었다. 따라서 본 연구에서는 과제의 지연시간을 8 초로 정하였다.

본 연구의 시연조건별 과제 특성을 정리하면 다음과 같다. 외현 적 시연조건은 비단어를 들려준 후 대상자로 하여금 그것을 8 초 동 안 소리내어 반복적으로 시연하게 한 다음 그대로 말하게 하는 과 제이다. 내현적 시연조건은 대상자로 하여금 제시된 비단어를 8 초 동안 마음속으로 반복적으로 시연하게 한 다음 그대로 말하게 하 는 과제이다. 시연 억제 조건은 비단어를 들려준 다음 8 초의 지연시 간 동안 노트북 화면에 시각적으로 제시되는 숫자들을 소리내어 읽게 한 후 앞서 제시되었던 비단어를 그대로 말하도록 하는 과제 이다. 화면의 숫자를 읽게 하는 것은 선행연구(Ellis, 1996)에 근거 하여 시연 또는 연상을 저지하기 위해 사용된 방법이었다.

$3,4,5$ 음절 총 45 개의 자극어를 A, B, C 세 세트의 실험과제에 15 개씩 할당하였다. 즉, $3,4,5$ 음절 항목 5 개씩을 중복되지 않게 분류 하여 $\mathrm{A}$ 세트 15항목, $\mathrm{B}$ 세트 15항목, $\mathrm{C}$ 세트 15항목으로 구성하였다 (Appendix 1). 이는 시연조건에 대한 자극어의 균형(counterbalance)을 맞추기 위해, 동일한 비단어 자극어가 하나의 시연조건에 반복 사용되지 않도록 하기 위한 것이었다. 대상자의 삼분의 일은 $\mathrm{A}$ 세트, $\mathrm{B}$ 세트, $\mathrm{C}$ 세트를, 또 다른 삼분의 일은 $\mathrm{B}$ 세트, $\mathrm{C}$ 세트, $\mathrm{A}$ 세트 를, 나머지 삼분의 일은 $\mathrm{C}$ 세트, $\mathrm{A}$ 세트, $\mathrm{B}$ 세트를 각각 외현적, 내현 적, 시연 억제 조건 과제에 이용하였다. 전체 대상자를 세 집단으로 나누어 A, B, C 세 세트 간 지연 비단어따라말하기 수행력을 비교 한 결과, 외현적 $\left(F_{(2,37)}=4.219, p>.05\right)$, 내현적 $\left(F_{(2,37)}=.694, p>.05\right)$, 시연억제 $\left(F_{(2,37)}=4.446, p>.05\right)$ 조건 모두에서 유의한 차이가 없었 다. 따라서 세 세트의 실험과제 자극어에 대한 난이도는 통제된 것 으로 간주하였다.

전산화된 지연 비단어따라말하기 과제 제작을 위해 $\mathrm{DmDx}$ Display Software (Forster \& Foster, 2003)를 사용하였다. 비단어 자극
어 제시 전 노트북 화면에 주의 집중을 위한 + 표시가 $1,000 \mathrm{~ms}$ 동 안 제시되고, $500 \mathrm{~ms}$ 의 inter stimuli interval (ISI) 후 비단어 자극 어가 청각적으로 제공되었다. 그러고 나서 8초 후 '삐'하는 신호음 이 나오면 대상자들로 하여금 그때 반응을 하게 하였다. 외현적 시 연과 내현적 시연조건에서는 8 초 동안 빈 화면이 제시되고, 시연 억 제 조건에서는 1 부터 9 까지 숫자들이 무작위로 제시되었다. 시연억 제 조건의 지연 비단어따라말하기 과제 구성 예는 Figure 1 과 같다.

\section{실험절차}

지연 비단어따라말하기 과제 실시

과제의 순서는 연습 항목, 본 항목 순으로 실시하였다. 외현적 시 연, 내현적 시연, 시연 억제의 순서는 무작위로 제시되었고, 각 시연 조건에서 15 개의 자극어도 무작위 순서로 제시되었다. 대상자의 반 응 여부에 상관없이, 각 실험항목에 대해 5 초 후에는 다음 항목으로 자동으로 넘어가게 되어 있었다.

아동들의 주의를 집중시킨 후 검사자는 "컴퓨터에서 들려주는 소리를 잘 듣고 똑같이 따라말하는 거예요. 그런데 바로 따라말하 는 것이 아니라 ‘삐' 소리가 나면 그 후에 말해야 해요.”라고 지시하 였다. 연구자는 연습항목을 훈련하기 전, 각 시연 방법에 대한 이해 를 돕기 위해 직접 시범을 보여주었다. 최대한 일정한 시연 속도를 유지하도록 시연 방법을 알려주었다. 시연조건 중 내현적 시연을 훈 련시키는 동안 검사자는 자극어 제시와 '삐' 소리 사이 기간에 검지 손가락을 입에 가져가 말을 하지 말하는 제스처를 취하면서 수차 례 반복 연습함으로써, 지연 시간 동안에는 따라말하면 안 되는 실 험규칙을 아동들에게 충분히 숙지시켰다. 그리고 외현적 시연조건 에서는 소리내어 따라말하기를, 내현적 시연조건에서는 소리내지 않고 입모양을 움직여 따라말하기를 훈련하였다. 내현적 시연조건 의 경우 마음속으로 시연을 실시하고 있는지 연구자가 확인할 수 있도록, Chung (2012)의 연구에 근거하여 소리는 내지 않되 입모양 은 움직일 것을 강조하였다. 시연 억제 조건에서는 지연 시간 동안 화면에 제시된 숫자를 소리내어 읽는 것을 반복 연습시켰다. 이때 숫자 읽기는 단순히 시연을 억제하기 위한 목적이어서 숫자 읽기의 정확성 여부는 고려하지 않았다. 다만 확실한 시연 억제를 위해 아

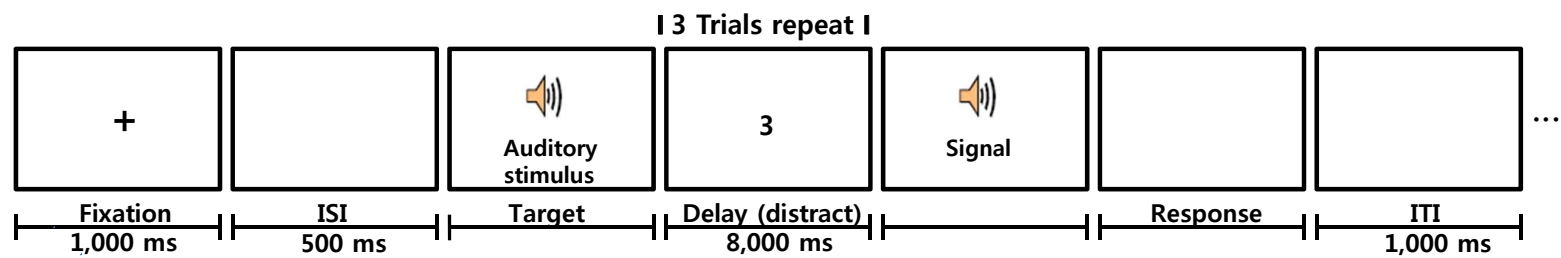

Figure 1. Delayed non-word repetition task. ISI= inter stimuli interval; ITI=inter trial interval. 
동에게는 숫자는 큰소리로 잘 읽어야 하는 것이라고 알려주고 충 분히 숙지시켰다. 아동이 실수하지 않고 연습 항목을 수행하는 것 을 확인한 후 본 실험에 착수하였다. 청각적 자극은 헤드셋을 통해 아동에게 전달되었고, 아동의 모든 반응은 헤드셋에 부착된 마이 크를 통해 노트북에 자동 녹음되었다. 자극어의 소리크기는 과제 수행 전 아동에게 의사를 물어 개별적으로 조절하였다.

\section{기타 과제 실시}

본 연구의 세 번째 연구질문인 말지각 능력, 단기기억 능력, 표현 어휘량과 지연 비단어따라말하기의 관계를 분석하기 위하여, 자음 변별검사, 숫자 바로따라하기 검사, 수용·표현어휘력검사를 실시하 였다. 자음변별검사는 Kwon (2004)의 연구에서 사용된 검사를 사 용하였는데, 이것은 자음+모음으로 이루어진 두 음절을 들려주고 같은지, 다른지를 판단하는 검사( 40 문항)이다. 숫자 바로따라하기 검사는 한국판 웩슬러아동용지능검사(Korean-Wechsler Intelligence Scale for Children, K-WISC-IV; Kwak, Oh, \& Kim, 2011)의 언어 소검사의 일부(16문항)를 사용하였다. 표현어휘량 측정을 위 해서는 수용·표현어휘력검사(REVT; Kim et al., 2009)의 표현어휘 과제를 사용하였는데, 이것은 대상아동 선정 시 실시하였던 검사 기록을 참고하였다.

\section{자료처리 및 통계분석}

지연 비단어따라말하기 과제에 대한 점수는 선행연구에 근거하 여(Kim \& Ha 2014), 정확한 조음위치에서 정확하게 조음한 자음 및 모음에 각 1 점씩을 부여한 후, 산출하여야 하는 총 음소에 대해 정확하게 산출한 음소가 차지하는 비율을 백분율로 구하였다. 따 라서 본 연구의 지연 비단어따라말하기 점수는 자극어에 대한 음 소 산출의 정확도(\%)를 의미한다. 오류유형 분석을 위해 오반응한 항목에 대한 대상자들의 반응을 모두 기록하였다. 이 가운데 1 회의 오류를 보인 유형은 제외하고, 2 회 이상 오류를 보인 유형들을 오류 유형 목록에 정리하였다. 목록에 포함된 오류유형은 무반응, 음절 생략, 음절대치, 음소첨가, 음소생략, 음소대치의 6가지로 분류되었 다. 오류유형의 비율은 대상자가 산출한 총 오류에 대해 각 오류유 형이 차지하는 비율을 백분율로 환산하여 구하였다.

Statistics package for the social science (SPSS, version 22.0 for Window)를 이용하여 다음과 같은 방법으로 자료의 통계분석을 실시하였다. 첫째, 연령집단(2) 간 시연조건(3)에 따른 지연 비단어 따라말하기 정확도를 비교하기 위해 1 피험자 간-1 피험자 내 혼합 분산분석(mixed ANOVA)을 실시하였다. 둘째, 연령집단(2) 간 시 연조건(3)에 따른 지연 비단어따라말하기 수행 시 나타난 오류유형
(6)별 비율을 알아보기 위해 1 피험자 간-2 피험자 내 혼합분산분석 을 실시하였다. 셋째, 각 과제 간 상관관계를 분석하기 위해 Pearson 적률 상관계수 분석을 실시하였고, 지연 비단어따라말하기 정 확도에 대한 예측 변수를 파악하기 위해 단계별 다중회귀분석(stepwise multiple regression)을 실시하였다.

\section{신뢰도}

지연 비단어따라말하기 과제 정확도에 대한 평가자 간 신뢰도를 구하기 위해, 연구자 1 인과 본 연구에 참여하지 않은 언어치료전공 대학원생 2 명이 자료 분석을 하였다. 전체 대상자의 $20 \%$ 에 해당하 는 8 명의 자료를 무작위로 추출하여 신뢰도를 산출하였다. 평가자 간 신뢰도는 일치된 평가 수를 일치된 평가 수와 불일치된 평가 수 의 합한 수로 나눈 다음 100 을 곱하여 계산하였다. 위와 같은 방법 으로 산출된 평가자 간 신뢰도는 $96.3 \%$ 였다.

\section{연구결과}

\section{집단 간 시연조건에 따른 지연 비단어따라말하기 정확도 비교}

시연조건에 따른 지연 비단어따라말하기 과제에서 6세 집단은 평균 52.55 (24.07)점, 7세 집단은 평균 70.65 (17.72)점의 정확도를 보였다(Figure 2). 혼합분산분석 결과 집단 간 주효과가 유의하여 $\left(F_{(1,38)}=36.347, p<.001\right), 7$ 세 집단은 6세 집단보다 정확도가 유의 하게 높다는 것을 알 수 있었다. 시연조건에 대한 주효과 $\left(F_{(1.228,46.672)}\right.$ $=172.36, p<.001)$ 와 집단과 시연조건 간 상호작용효과 또한 유의 하였다 $\left(F_{(2,46.672)}=5.533, p<.01\right)$. 시연조건에 따른 차이를 구체적으 로 알아보기 위하여 Bonferroni 사후검정을 실시한 결과, 외현적 시연조건은 나머지 두 조건에서보다, 내현적 시연조건은 시연 억제

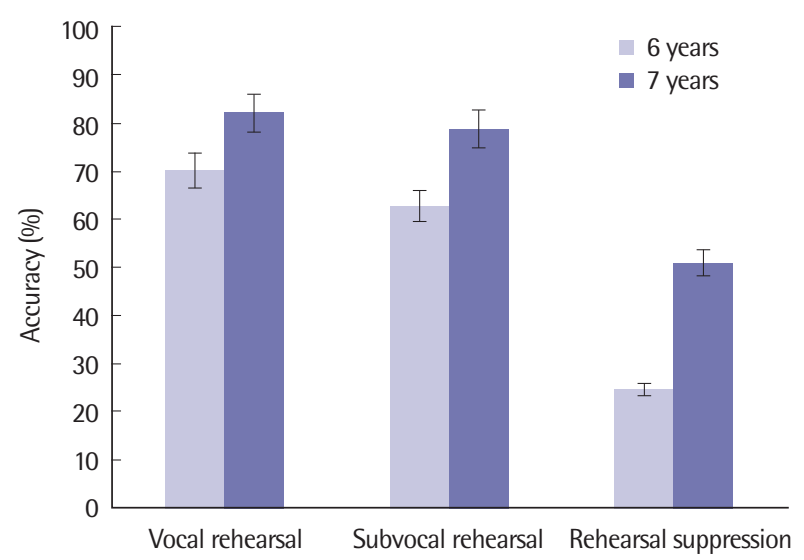

Figure 2. The accuracy of delayed non-word repetition tasks according to rehearsal conditions. 
조건에서보다 정확도가 유의하게 높은 것으로 나타났다 $(p<.001)$. 마지막으로 집단과 시연조건 간 상호작용효과를 구체적으로 알아 보기 위하여, COMPARE 하위명령어를 입력한 syntax를 실행시켜 사후검정을 실시하였다(Howell \& Lacroix, 2012). 그 결과 6세 집단 은 외현적 시연조건, 내현적 시연조건, 시연 억제 조건 순으로 유의 하게 높은 정확도를 보였다 $(p<.001)$. 반면 7세 집단의 경우 외현적 및 내현적 시연조건에서의 정확도가 시연 억제 조건보다 좋은 것은 동일하였으나 외현적 시연조건과 내현적 시연조건 간에는 유의한 차이가 없었다( $p>.05$ ) (Figure 2).

\section{집단 간 시연조건에 따른 지연 비단어따라말하기 오류유형 비율 비교}

두 연령집단 간 시연조건에 따른 지연 비단어따라말하기 오류유 형 비율에 유의한 차이가 있는지 알아보았다. 6 세 집단의 경우 외현 적 시연조건에서 음소대치 $51.40 \%$ (2.88\%), 음소생략 $23.75 \%$ (2.23\%), 음절대치 $11.90 \%$ (1.46\%), 음소첨가 5.95\% (.89\%), 무반응 $4.45 \%$ (1.55\%), 음절생략 $2.80 \%$ (1.11\%) 순으로, 내현적 시연조건에서 음 소대치 $46.25 \%$ (2.79\%), 음소생략 $21.30 \%$ (2.71\%), 무반응 $12.50 \%$ (3.62\%), 음절대치 9.65\% (1.49\%), 음소첨가 7.45\% (1.20\%), 음절생 략 3.05\% (1.08\%) 순으로, 시연 억제 조건에서 무반응 $46.90 \%$ (8.34\%), 음소대치 $21.40 \%$ (3.55\%), 음소생략 $12.50 \%$ (2.32\%), 음절대치 $11.35 \%$ (3.07\%), 음절생략 $5.35 \%$ (2.30\%), 음소첨가 $2.60 \%$ (.73\%) 순으로 오 류유형 비율을 나타내었다. 7세 집단의 경우 외현적 시연조건에서 음소대치 $51.95 \%$ (2.55\%), 음소생략 $31.15 \%$ (3.74\%), 음소첨가 $8.30 \%$ (1.47\%), 음절대치 6.00\% (1.34\%), 음절생략 $1.80 \%$ (.71\%), 무반응 $.95 \%$ (.70\%) 순으로, 내현적 시연조건에서 음소대치 $52.45 \%$ (2.19\%), 음소생략 $35.40 \%$ (2.91\%), 음절대치 5.85\% (1.17\%), 음소첨가 3.85\% (.66\%), 음절생략 $1.90 \%(.91 \%)$, 무반응 $.75 \%(.41 \%)$ 순으로, 시연 억 제 조건에서 음소대치 $41.05 \%$ (3.21\%), 음소생략 $21.05 \%$ (3.01\%), 음 절대치 $14.25 \%$ (2.69\%), 무반응 $11.70 \%$ (5.00\%), 음절생략 $6.05 \%$ (1.31\%), 음소첨가 $5.95 \%$ (.86\%) 순으로 오류유형 비율을 나타내었다.

혼합분산분석 결과 집단 간 주효과는 유의하지 않았으나 $\left(F_{(1,38)}=.238, p>.05\right)$, 이는 전체 오류에 대한 각 오류유형의 비율을 백분율로 구하여 비교하였기 때문에 나타난 당연한 결과이다. 오 류유형에 따른 주효과 $\left(F_{(2.539,96.486)}=113.97, p<.001\right)$, 집단과 오류유 형에 대한 상호작용효과 $\left(F_{(2.539,96.486)}=11.421, p<.001\right)$, 시연조건과 오류유형에 대한 상호작용효과가 모두 유의하였다 $\left(F_{(2.776,105.48)}=\right.$ $23.825, p<.001)$. 또한 집단, 시연조건에 대한 삼요인 상호작용효과 도 유의한 것으로 나타났다 $\left(F_{(2.776,105.48)}=6.423, p<.001\right)$.

오류유형에 대한 주효과를 구체적으로 알아보기 위하여 Bon- ferroni 사후검정을 실시하였다. 그 결과 음소대치는 나머지 다섯 반응유형보다, 음소생략은 음절생략, 음절대치, 음소첨가보다, 음 절대치는 음절생략보다 유의하게 많았다 $(p<.001)$. 집단과 오류유 형, 시연조건과 오류유형의 이요인 상호작용효과를 각각 분석하기 위하여, COMPARE 하위명령어를 입력한 syntax를 실행시켜 사후 검정을 실시하였다. 그 결과 6세 집단은 7세 집단보다 무반응을, 7 세 집단은 6세 집단보다 음소대치와 음소생략을 유의하게 많이 나 타냈다 $(p<.001)$. 그리고 무반응은 외현적 시연과 내현적 시연보다 시연 억제 조건에서 $(p<.001)$, 음소생략과 음소대치는 시연 억제보 다 외현적 시연과 내현적 시연조건에서 유의하게 많이 나타났다 $(p<.001)$.

마지막으로 집단, 시연조건, 오류유형에 대한 삼요인 상호작용효 과를 구체적으로 살펴보기 위하여, LMATRIX \& MMATRIX 하위 명령어를 입력한 syntax를 실행시켜 사후검정을 실시하였다(Howell \& Lacroix, 2012). 그 결과 6세 집단의 경우 무반응은 외현적 및 내현적 시연보다 시연 억제 조건에서 $(p<.001)$, 음소생략은 시연 억 제보다 외현적 시연조건에서( $p<.001)$, 그리고 음소대치는 시연 억제 보다 외현적 및 내현적 시연조건에서 유의하게 많이 나타났다 $(p<$ .001) (Figure 3). 반면 7세 집단의 경우는 음소생략만 시연 억제보다 내현적 시연조건에서 유의하게 많이 나타났다 $(p<.001)$ (Figure 4$)$.

\section{지연 비단어따라말하기 정확도와 말지각 능력, 단기기억 능력, 어휘량의 관계}

지연 비단어따라말하기 정확도와 자음변별, 숫자 바로따라하기, 표현어휘 점수의 상관관계

각 과제 간 상관관계 분석결과를 언급하기에 앞서, 연령집단별 자음변별, 숫자 바로따라하기, 표현어휘검사 점수를 정리해보면 다

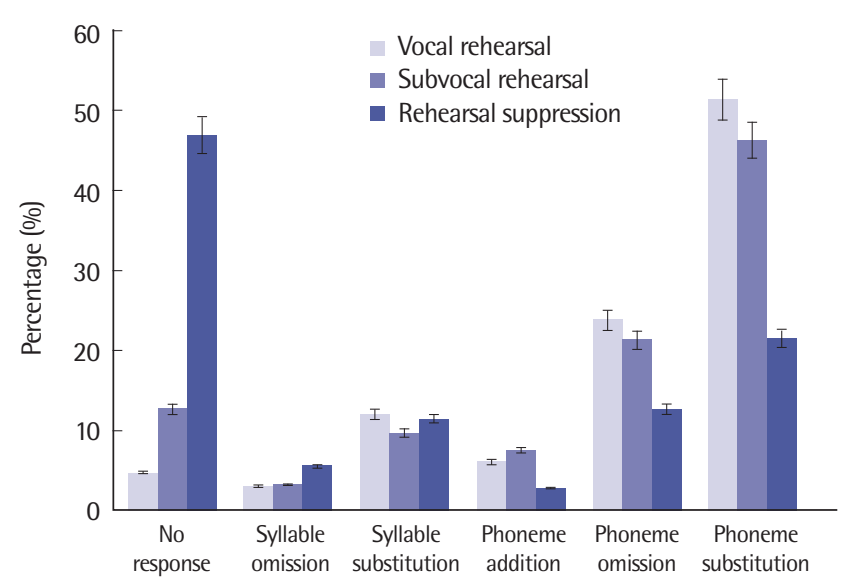

Figure 3. The percentage of error types in 6-year-old children. 


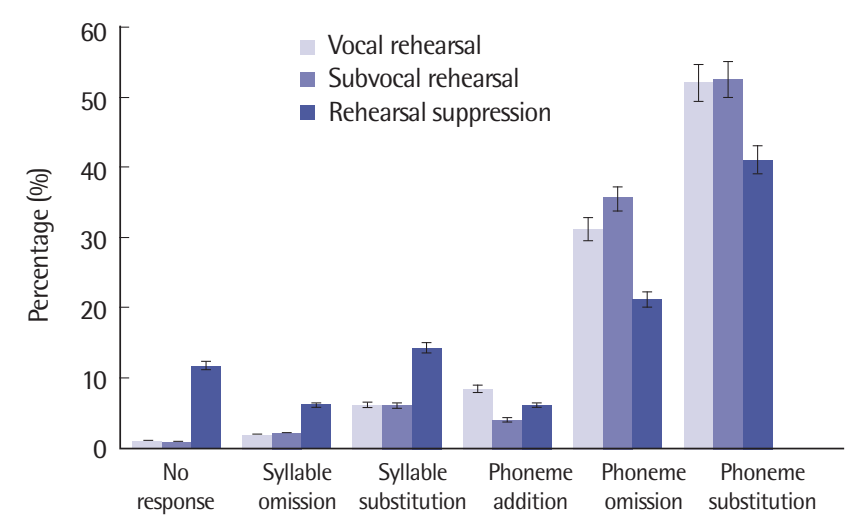

Figure 4. The percentage of error types in 7-year-old children.

Table 1. The Pearson correlation coefficient between the vocal rehearsal and variables

\begin{tabular}{lccc}
\hline & Score 1 & Score 2 & Score 3 \\
\hline Vocal rehearsal & - & & \\
Consonant discrimination & $.649^{* * *}$ & - & \\
Digit forward & $.608^{* * *}$ & $.818^{* * *}$ & - \\
Expressive vocabulary & $.588^{* * *}$ & $.611^{* * *}$ & $.575^{* * *}$ \\
\hline
\end{tabular}

${ }^{* * *} p<.001$.

음과 같다. 자음변별검사는 6세 평균 36.70 (1.45)점, 7세 평균 38.30 (1.10)점, 숫자 바로따라하기 검사는 6세 평균 11.50 (2.04)점, 7세 평 균 13.20 (1.69)점, 표현어휘검사 원점수는 6세 평균 70.00 (2.79)점, 7 세 평균 80 (3.58)점이었다. 모든 시연조건에서 지연 비단어따라말 하기 정확도는 자음변별, 숫자 바로따라하기, 표현어휘량과 유의하 게 상관이 높거나 상관이 있는 것으로 나타났다 $(p<.001)$ (Tables $1-3)$.

지연 비단어따라말하기 정확도의 예측변수

자음변별, 숫자 바로따라하기, 표현어휘량을 예측변수로 하여 다중회귀분석을 실시하였다. 그 결과 지연 비단어따라말하기 정확 도에 유의하게 영향을 미치는 변수는 외현적 시연조건에서는 숫자 바로따라하기 $(t=3.412, p<.01)$, 내현적 시연조건에서는 자음변별 $(t=4.153, p<.001)$, 시연 억제 조건에서는 자음변별 $(t=5.294, p<$ .001)과 표현어휘량 $(t=2.658, p<.01)$ 순으로 분석되었다. 외현적 시 연조건에서 지연 비단어따라말하기 정확도 총 변화량의 $59 \%$ (수 정 결정계수에 의하면 57\%)가 모형에 포함된 1 개의 독립변수(숫자 바로따라하기)에 의해 설명되었고, 내현적 시연조건에서는 총 변화 량의 $64 \%$ (수정 결정계수에 의하면 62\%)가 모형에 포함된 1개의 독 립변수(자음변별)에 의해 설명되었다. 그리고 시연 억제 조건에서 는 총 변화량의 69\% (수정 결정계수에 의하면 67\%)가 모형에 포함
Table 2. The Pearson correlation coefficient between the subvocal rehearsal and variables

\begin{tabular}{lccc}
\hline & Score 1 & Score 2 & Score 3 \\
\hline Subvocal rehearsal & - & & \\
Consonant discrimination & $.711^{* * *}$ & - & \\
Digit forward & $.579^{* * *}$ & $.819^{* * *}$ & - \\
Expressive vocabulary & $.689^{* * *}$ & $.611^{* * *}$ & $.575^{* * *}$ \\
${ }^{* * *} p<.001$. & & &
\end{tabular}

Table 3. The Pearson correlation coefficient between the rehearsal suppression and variables

\begin{tabular}{lccc}
\hline & Score 1 & Score 2 & Score 3 \\
\hline Rehearsal suppression & - & & \\
Consonant discrimination & $.796^{* * *}$ & - & \\
Digit forward & $.669^{* * *}$ & $.818^{* * *}$ & - \\
Expressive vocabulary & $.679^{* * *}$ & $.611^{* * *}$ & $.575^{* * *}$ \\
${ }^{* * *} p<.001$. & & &
\end{tabular}

된 2개의 독립변수(자음변별, 표현어휘량)에 의해 설명되었다.

\section{논의 및 결론}

집단 간 시연조건에 따른 지연 비단어따라말하기 정확도를 비교 한 결과, 모든 시연조건에서 6세 집단보다 7세 집단의 수행력이 유 의하게 좋았다. 이는 연령이 높아짐에 따라 음운단기기억 능력이 발달한다는 선행연구와 일치하는 결과이다(Bjorklund et al., 1997; DeLoache et al., 1985; Kim, 1997). 그리고 시연 억제보다 외현적 시 연과 내현적 시연에서 지연 비단어따라말하기 정확도가 유의하게 높은 것으로 나타났다. 즉, 외현적이든 내현적이든, 시연을 하는 것 이 시연을 하지 않는 것보다 음운단기기억력에 도움이 된다는 것을 알 수 있다. 이 또한 시연을 사용한 경우와 사용하지 않은 경우를 비교한 많은 선행연구들과 일치하는 결과이다(Fletcher \& Bray, 1996; Kim, 2012; Loomes et al., 2007; Oxley \& Norris, 2000).

본 연구에서 흥미로운 결과는 6세 집단에서는 외현적 시연과 내 현적 시연조건 간 유의한 차이가 나타난 반면, 7 세 집단의 경우 내 현적 시연보다 외현적 시연조건에서 평균적으로는 수행력이 좋았 지만 그 차이가 통계적으로 유의하지는 않았다는 것이다. 실험 전 연구자들은 외적 청각입력(external auditory input)이 시연과정에 동반되는 외현적 시연에서 과제 수행력이 유의하게 가장 높을 것이 라고 예상하였으나, 실험결과 이것은 6세에만 해당하였다. 이러한 결과는 7세가 되면 소리 내지 않고 마음속으로 정보를 되뇌이는 것 만으로도 기억향상에 충분한 이득을 얻을 수 있다는 것을 시사한 다. 6세보다 7세에서 자발적 시연전략을 적극 활용한다는 Keeney, 
Cannizzo와 Flavell (1967)과 Kim (1997)의 연구, 특정 연령대 이후 부터 외현적 시연보다 내현적 시연이 오히려 더 효과적이라는 Song (1995)의 연구, 그리고 본 연구의 결과들을 종합하여 고찰해볼 때 다음과 같은 해석이 가능하다. 시연전략 사용이 아직 능숙하지 않 은 6세 (Kim, 1997)의 경우에는, 주어진 정보를 말로 표현할수록 (vocalization) 회상력이 높아진다는 가설(Murray, 1965)이 적용될 수 있다. 그러나 7세부터는 자발적으로 시연전략을 사용하여 기억 과정을 통제할 수 있는 충분한 인지적 조작 능력이 생겨나(Song, 1995), 겉으로 드러내지 않고 마음속으로 되뇌이는 활동을 통해 정 보의 보유량을 효과적으로 늘려나갈 수 있다. 이러한 해석은 연령 이 높아지면서 외현적 언어에서 내현적 언어로 변화하고 외현적 언 어 없이 내현적 언어만으로 자신의 행동을 수행하고 통제한다는 언어중재 이론(Luria, 1961; Vygotsky, 1962)과 맥락을 같이 한다. 그뿐만 아니라 성인의 기억과정을 설명하기 위해 출발한 Baddeley (1986)의 작업기억 모델에서 시연활동이 왜 내현적 시연에 가까운 지도 추측하게 해준다. 따라서 음운단기기억력을 향상시키기 위해 서는 어린 연령의 아동에게는 시연활동을 의도적으로 사용할 수 있도록 우선적으로 외현적 시연전략을 지도하는 것이 필요하고, 이 후 시연활동에 익숙해져 그것을 자발적이고 능동적으로 사용할 수 있게 되면 보다 자연스러운 내현적 시연에 익숙해지도록 하는 것이 효과적일 것이다.

지연 비단어따라말하기 과제 수행 시 나타난 오류유형의 비율을 비교한 결과, 시연조건에 상관없이 6세 집단은 7세 집단보다 무반 응을, 7 세 집단은 6 세 집단보다 음소대치와 음소생략을 유의하게 많이 보였다. 다시 말해 과제를 성공적으로 수행하지 못하였을 때 높은 연령의 아동은 분절음 차원의 부분적 실수를 많이 보이는 반 면, 어린 연령의 아동은 전혀 적절한 반응을 하지 못한 경우가 많았 다. 그러나 시연조건과 오류유형의 상호작용효과 분석을 통해 시연 활동이 오류유형에 미치는 영향을 살펴보면, 연령집단에 상관없이 시연 억제 조건에서는 나머지 두 조건에서보다 무반응이, 외현적 및 내현적 시연조건에서는 시연 억제 조건에서보다 음소생략과 음 소대치가 많이 나타났다. 이는 시연을 활용하면 주어진 정보를 좀 더 많이 보유할 수 있다는 것이다. 6 세 집단의 경우에도 외현적 또 는 내현적 시연을 활용하면 음소대치 또는 음소생략의 오류가 유의 하게 증가하여, 시연전략은 6세 아동의 반응을 목표 자극에 근접시 키는 데에 도움이 된다는 것을 확인할 수 있다. 그러나 집단, 시연조 건, 오류유형의 삼요인 상호작용효과 분석을 통해 7세에 이르러 6 세와 유의하게 달라진 점 또한 확인할 수 있는데, 7세 집단의 경우 모든 시연조건에서 가장 많이 나타난 오류유형이 음소대치라는 것 이다(Figure 4). 7세 집단에서 시연조건 간 음소대치의 비율에 통계
적으로 유의한 차이가 나타나지 않는 점으로 미루어, 이 연령에 이 르면 음운단기기억 능력이 향상되면서 어떠한 시연조건이 주어지 더라도 직면하는 어려움은 질적으로는 크게 다르지 않다는 것을 유추할 수 있다.

본 연구결과 모든 시연조건에서 지연 비단어따라말하기 수행력 은 자음변별 능력, 숫자 바로따라하기 능력, 표현어휘량과 유의한 정적 상관관계가 있었다. 그러나 과제 수행에 영향을 미치는 예측 변수는 시연조건별로 상이하게 나타났다. 지연 비단어따라말하기 정확도를 유의하게 예측하는 변수는 외현적 시연에서는 숫자 바로 따라하기, 내현적 시연에서는 자음변별, 시연 억제에서는 자음변별 과 표현어휘량이었다. 이는 동일한 과제라도 어떠한 시연조건하에 서 이루어지느냐에 따라 그것의 수행에 유의하게 영향을 주는 요인 이 다르다는 것을 시사한다. 이것은 시연조건의 특성이 과제 수행 시 대상자들에게 요구하는 능력을 변화시킬 수 있다는 관점에서 해석이 가능할 것이다.

우선 외현적 시연조건의 경우, 지연 시간 동안 자극어를 소리 내 어 말하게 함으로써 대상자에게 요구되는 능력이 숫자 바로따라하 기 수행 시 요구되는 것과 결과적으로 같아진 것으로 추측해볼 수 있다. Lee (2010)는 아동의 생활연령이 높을수록, 어휘능력이 높을 수록, 숫자 바로따라하기 능력이 높을수록 비단어따라말하기 수행 력이 높게 나타났고, 이 가운데 특히 숫자 바로따라하기와 비단어 따라말하기 수행력 사이에 유의하게 높은 정적 상관관계가 있다고 하였다. 그 이전에도 이와 유사한 결과들이 여러 다른 선행연구들 (Campbell, Dollaghan, Needleman, \& Janosky, 1997; Gathercole, 1995)에서 보고된 바 있다. 그런데 이 연구들에서 사용된 과제는, 본 연구와 달리, 즉각 비단어따라말하기 과제였다. 숫자 바로따라 하기와 즉각 비단어따라말하기는 제시된 자극어를 시간적 지연 없 이 바로 따라말하게 하는 과제절차상 공통점을 가지며, 두 과제는 단순히 자극에 대한 수동적 저장공간으로서의 단기기억력을 요구 하는 과제이다. 본 연구의 경우 자극어 제시와 대상자의 반응 사이 에 8 초라는 시간적 간격을 두어 수동적 저장공간 이상의 기능을 요 구하는 과제였지만, 지연 시간 동안 대상자들에게 소리 내어 자극 어를 말하게 함으로써 그 과제의 성격이 즉각 비단어따라말하기와 유사하게 변화된 것으로 여겨진다.

반면 자음변별 능력이 예측변수로 분석된 내현적 시연조건은, 시 연조건을 달리함에 따라, 외현적 시연조건의 과제와 다른 차원의 과제로 변화한 것으로 보인다. 본 연구에서 사용한 자음변별 과제 는 말소리 간 음운적 유사점과 차이점을 민감하게 감지할 수 있는 능력을 요구한다(Ball, 1993). 내현적 시연조건의 경우 대상자들로 하여금 시연활동은 하되 외적으로 소리 내는 것을 금지하였기 때 
문에, 시연이 허용된 시간 동안 아동들은 음성적 차원이 아닌 음운 적 차원의 말소리에 의존하여 들었던 자극어와 유사한 소리조합을 음운적으로 형성하는 작업을 반복하였을 것이다. 이러한 작업 동 안 조금 전 들었던 비단어와 현재 머릿속에서 되뇌이는 비단어 사 이의 음운 차원의 유사점과 차이점을 민감하게 변별하기 위해서는 기본적으로 자음변별 능력, 즉 말지각 능력이 요구될 것이다. 더 나 아가 이것은 일종의 내적 모니터링(internal monitoring) 과정으로 볼 수 있으며, 8 초 전 들었던 자극어를 성공적으로 부호화하기 위 해서는 시연 과정 내내 이러한 내적 모니터링 기제가 효율적으로 작동하여야 할 것이다. 말지각 능력이 떨어지는 환자는 내적 모니터 링 능력에도 결함을 보였다는 선행연구(Schlenck, Huber, \& Willmes, 1987)는 이러한 연구자들의 추측과 맥락을 같이 한다. 자음변별 능 력이 좋을수록 마음속으로 시연하는 능력도 좋다는 본 연구의 결 과는 이와 같은 해석에 근거할 때 설득력이 있는 것으로 보인다.

시연 억제 조건에서는 자음변별 능력과 표현어휘량이 그 수행력 을 예측하는 것으로 나타났다. 이러한 결과는 소리 내어 숫자 읽기 를 하게 함으로써 시연을 억제시켰더라도, 대상자들은 방금 전 들 었던 자극어와 유사한 소리조합을 자신의 머릿속에 맴돌게 하려는 별도의 내현적 시연 노력을 하고 있었을 것이라고 추측하게 한다. 그뿐만 아니라 세 가지 시연조건 가운데 시연 억제 조건은 가장 난 이도가 높은 과제이다. 어려운 조건에서 실험에 적극적으로 임하는 대상자들은 본인이 가지고 있는 여러 인지능력들을 총동원하고자 할 것이며, 본 연구의 결과는 이러한 대상자들의 노력이 반영된 것 으로 보인다. 어휘는 장기기억 속에 저장되어 있는 지식이다. 아동 들은 시연활동이 억제되고 숫자라는 방해자극을 읽어야 하는 상 황에서도 과제를 성공적으로 수행하기 위해, 장기기억 속에 저장되 어 있는, 방금 전 들었던 자극어와 유사한 형태의 어휘를 떠올리며 음운완충기(phonological buffer) 내에 비단어 자극어를 유지하려 는 하향접근적 노력(top-down approach)을 하였을 것이다. 비단어 따라말하기 수행력과 어휘 능력 간 밀접한 관련성을 가진다는 선 행연구(Gathercole, 1995)에 의해, 비단어따라말하기는 상향적 접 근뿐 아니라 하향적 접근 능력 또한 요구하는 과제라는 것은 이미 밝혀진 바 있다. 나아가 본 연구의 결과는 제시된 정보를 음운완충 기에 보유하는 데에 어려움에 직면하였을 때 하향적 접근이 보다 활발하게 작동한다는 것을 시사한다.

본 연구는 시연활동으로 아동들이 더 많은 정보를 단기기억에 저장하고 보유할 수 있다는 것을 제시하였다. 시연활동을 외현적, 내현적으로 구분하였을 때, 일반아동의 경우 6세에는 외현적 시연 이 더 효과적이지만, 7 세가 되면 내현적 시연으로도 충분히 이득을 얻을 수 있다는 것 또한 제안하고 있다. 기억책략 중 시연책략이 가
장 먼저 발달하고, 그 연령이 6-7세경이라는 선행연구에 근거할 때 (Vasta et al., 1992), 본 연구의 6세 집단은 시연활동이 출현하고 있 는 시기의 아동들, 7 세 집단은 시연활동에 좀 더 익숙해진 아동들 로 볼 수 있다. 따라서 시연활동에 아직 익숙하지 않은 아동들을 대 상으로 기억력을 이용한 학습을 실시할 때에는, 정보를 소리 내어 말하도록 하는 것이 도움이 될 것이다. 모든 언어학습은 기억을 전 제로 한다. 언어학습에 어려움을 보이는 언어발달장애 아동에 대 해 언어 자체뿐 아니라 단기기억, 작업기억 등의 결함이 여러 연구 들에서 보고되었다. 이들의 언어치료에도 기억을 이용한 교육이 필 수적이기 때문에, 기억활동 시 시연, 특히 초기에는 외현적 시연을 적극 활용하는 것은 분명 효과가 있을 것이다. 그 이유는 대상자들 의 기억 범위를 초과하는 과제이더라도 외현적 시연을 사용하게 함 으로써, 해당 과제를 수동적 저장공간으로서의 단기기억 정도만을 요구하는, 복잡하지 않은 기억처리를 요구하는 과제로 어느 정도 변화시킬 가능성이 있기 때문이다.

아동이 태어나 처음으로 어떤 단어를 접하게 될 때, 당시 아동에 게 그 단어는 단지 '비단어'였을 뿐이다. 새로운 소리의 조합인 비단 어에 의미가 더해져 그것을 반복 경험하게 되면 비로소 그것은 아 동의 어휘저장소인 장기기억에 '단어'로 자리를 잡게 된다. 이와 같 은 이유로 비단어 처리에 문제를 보이는 아동은 어휘습득에 제한 을 보일 수밖에 없다. 그뿐만 아니라 비단어 처리과정에 저장된 어 휘량이 하향적 영향을 미친다는 연구결과들 또한 고려할 때, 어휘 력에 결함을 보이는 언어장애아동들의 어휘발달의 악순환에 대해 서도 추측해볼 수 있다. 비단어 처리가 음운단기기억을 바탕으로 하는 작업인 만큼 시연효과와 관련한 본 연구의 결과는 분명 언어 발달장애 분야에 시사하는 바가 있을 것이다.

이와 같은 연구결과의 의의에도 불구하고, 본 연구는 외현적 시 연과 내현적 시연 시 시연 속도에 대한 통제를 하지 못하였다는 방 법상의 제한점을 가지고 있다. 본 실험 전 연구자는 최대한 시연 속 도를 일정하게 유지하도록 연습시켰으나, 대상 아동들은 8초 동안 의 시연 시간 동안 제각각 속도를 달리하여 시연을 실시하였다. 적 은 수의 시연보다 많은 수의 시연이 음운단기기억에 긍정적인 영향 을 미친다는 선행연구(Moon, 1994)에 근거할 때, 추후연구에서는 시연 속도의 통제가 반드시 이루어져야 할 것이다. 또한 대상자들 이 6, 7세 일반아동으로 한정되어 있고 각 연령집단 내에서도 대상 자 수가 충분하지 않아 연구결과를 일반화하는 데에는 분명 제한 이 있다. 따라서 추후 대상자 수를 좀 더 확보하여 보다 신뢰할 수 있는 결과를 도출하도록 하여야 할 것이며, 5 세 이하, 8 세 이후의 일 반아동 및 언어장애아동들을 대상으로도 시연과 관련한 연구가 활발하게 이루어져야 할 것이다. 본 연구가 이러한 후속연구들에 
기초연구로서 도움이 될 것으로 기대한다.

\section{REFERENCES}

Alt, M., \& Spaulding, T. (2011). The effect of time on word learning: an examination of decay of the memory trace and vocal rehearsal in children with and without specific language impairment. Journal of Communication Disorders, 44, 640-654.

Atkinson, R. C., \& Shiffrin, R. M. (1968). Human memory: a proposed system and its control processes. Psychology of Learning and Motivation, 2, 89-195.

Baddeley, A. (1986). Working memory. London: Oxford University Press.

Baddeley, A. (2000). The episodic buffer: a new component of working memory? Trends in Cognitive Sciences, 4, 417-423.

Baddeley, A., Gathercole, S., \& Papagno, C. (1998). The phonological loop as a language learning device. Psychological Review, 105, 158-173.

Ball, E. W. (1993). Assessing phoneme awareness. Language, Speech, and Hearing Services in Schools, 24, 130-139.

Bjorklund, D. F., Miller, P. H., Coyle, T. R., \& Slawinski, J. L. (1997). Instructing children to use memory strategies: evidence of utilization deficiencies in memory training studies. Developmental Review, 17, 411-441.

Brookshire, R. H. (2007). Introduction to neurogenic communication disorders (7th ed.). St. Louis, MO: Mosby Elsevier.

Campbell, T., Dollaghan, C., Needleman, H., \& Janosky, J. (1997). Reducing bias in language assessment processing-dependent measures. Journal of Speech, Language, and Hearing Research, 40, 519-525.

Chung, Y. S. (2012). The effect of manipulating the articulatory suppression behavior on the performance of working memory system (Doctoral dissertation). Seoul National University, Seoul, Korea.

Chung, Y. S., \& Kim, J. O. (2010). Articulatory suppression in immediate serial recall: does overt suppression suppress subvacal rehearsal? Korean Journal of Cognitive and Biological Psychology, 22, 311-335.

Cleary, M., Pisoni, D. B., \& Geers, A. E. (2001). Some measures of verbal and spatial working memory in eight-and nine-year-old hearing-impaired children with cochlear implants. Ear and Hearing, 22, 395-411.

Cohen, R. L., \& Heath, M. (1990). The development of serial short-term memory and the articulatory loop hypothesis. Intelligence, 14, 151-171.

DeLoache, J. S., Cassidy, D. J., \& Brown, A. L. (1985). Precursors of mnemonic strategies in very young children's memory. Child Development, 56, 125137.
Dollaghan, C., \& Campbell, T. F. (1998). Nonword repetition and child language impairment. Journal of Speech, Language, and Hearing Research, 41, 1136-1146.

Edwards, J., Beckman, M. E., \& Munson, B. (2004). The interaction between vocabulary size and phonotactic probability effects on children's production accuracy and fluency in nonword repetition. Journal of Speech, Language, and Hearing Research, 47, 421-436.

Ellis, N. C. (1996). Working memory in the acquisition of vocabulary and syntax: putting language in good order. Quarterly Journal of Experimental Psychology Section A, 49, 234-250.

Ellis, N. R. (1970). Memory processes in retardates and normals. International Review of Research in Mental Retardation, 4, 1-32.

Fletcher, K. L., \& Bray, N. W. (1996). External memory strategy use in preschool children. Merrill-Palmer Quarterly, 42, 379-396.

Forster, K. I., \& Forster, J. C. (2003). DMDX: a Windows display program with millisecond accuracy. Behavior Research Methods, Instruments, \& Computers, 35, 116-124.

Gathercole, S. E. (1995). Is nonword repetition a test of phonological memory or long-term knowledge? It all depends on the nonwords. Memory \& Cognition, 23, 83-94.

Gathercole, S. E., Willis, C., \& Baddeley, A. D. (1991). Differentiating phonological memory and awareness of rhyme: reading and vocabulary development in children. British Journal of Psychology, 82, 387-406.

Greene, R. L. (1987). Effects of maintenance rehearsal on human memory. Psychological Bulletin, 102, 403-413.

Howell, G. T., \& Lacroix, G. L. (2012). Decomposing interactions using GLM in combination with the COMPARE, LMATRIX and MMATRIX subcommands in SPSS. Tutorials in Quantitative Methods for Psychology, 8, 1-22.

Hwang, M. (2015). Nonword repetition of typically developing children. Communication Sciences \& Disorders, 20, 374-385.

Jo, N. H. (2002). The frequency of modern Korean words. Seoul: National Institute of the Korean Language.

Keeney, T. J., Cannizzo, S. R., \& Flavell, J. H. (1967). Spontaneous and induced verbal rehearsal in a recall task. Child Development, 38, 953-966.

Kim, H. J., Choi, S. Y., \& Ha, J. W. (2015). Speech-motor program/programming in children with childhood apraxia of speech, children with articulatory and phonological disorders and typically developing children. Communication Sciences \& Disorders, 20, 60-71.

Kim, H. K., \& Kang, B. M. (1997). The analysis of Korean word frequency. Seoul: Korea University, Research Institute of Korea Studies. 
Kim, J. Y. (1988). A study on the use of categorical organization in child's memory (Master's thesis). Ewha Womans University, Seoul, Korea.

Kim, N. Y., \& Ha, J. W. (2014). Phonological representations in children with articulation and phonological disorders. Communication Sciences \& Disorders, 19, 226-237.

Kim, O. H. (1997). Effects of continuity and interval time in verbal rehearsals on recall. Early Childhood Education Research \& Review, 1, 239-262.

Kim, Y. G. (2012). The effects of the memory strategy for the recall memory and the implication for occupational therapy. Journal of Korean Society of Cognitive Rehabilitation, 1, 5-21.

Kim, Y. T, Hong, G. H., Kim, K. H., Jang, H. S., \& Lee, J. Y. (2009). Receptive \& expressive vocabulary test (REVT). Seoul: Seoul Community Rehabilitation Center.

Kim, Y. T., \& Shin, M. J. (2004). Urimal test of articualtion and phonology (UTAP). Seoul: Hakjisa.

Kwak, K. C., Oh, S. W., \& Kim, C. T. (2011). Korean-wechsler intelligence scale for children-IV (K-WISC-IV). Seoul: Hakjisa.

Kwon, M. S. (2004). Evolution of aphasia profile and auditory comprehension ability in wernicke's aphasia (Doctoral dissertation). Ewha Womans University, Seoul, Korea.

Lee, D. H. (2015). Performances of immediate and delayed phonological shortterm memory according to the aging of normal adult. Daegu University, Gyeongbuk, Korea.

Lee, H. J. (2010). The influences of number of syllables and wordlikeness on 3to 5-year-old Korean-English bilingual children's nonword repetition (Master's thesis). Ewha Womans University, Seoul, Korea.

Loomes, C., Rasmussen, C., Pei, J., Manji, S., \& Andrew, G. (2008). The effect of rehearsal training on working memory span of children with fetal alcohol spectrum disorder. Research in Developmental Disabilities, 29, 113-124.

Luria, A. R. (1961). The role of speech in the regulation of normal and abnormal behavior. New York, NY: Liveright.

Moon, S. M. (1994). Development of learning strategies and academic performance. Korean Journal of Educational Research, 32, 47-74.
Munson, B., Edwards, J., \& Beckman, M. E. (2005). Relationships between nonword repetition accuracy and other measures of linguistic development in children with phonological disorders. Journal of Speech, Language, and Hearing Research, 48, 61-78.

Murray, D. J. (1965). Vocalization-at-presentation and immediate recall, with varying presentation-rates. Quarterly Journal of Experimental Psychology, $17,47-56$.

Oxley, J., \& Norris, J. (2000). Children's use of memory strategies: relevance to voice output communication aid use. Augmentative and Alternative Communication, 16, 79-94.

Paik, S. J., Ahn, S. W., Seo, Y. K., \& Shin, Y. J. (2007). Working memory of normal children and childern with reading disability. Journal of Emotional \& Behavioral Disorders, 23, 265-300.

Papalia, D. E., Olds, S. W., \& Feldman, R. D. (2002). A child's world: infancy through adolescence (9th ed.). New York, NY: McGraw-Hill.

Park, Y. A. (2007). Utilization deficiency and metamemory in children's use of memory strategy (Doctoral dissertation). Sungkyunkwan University, Seoul, Korea.

Salamé, P., \& Baddeley, A. (1982). Disruption of short-term memory by unattended speech: implications for the structure of working memory. Journal of Verbal Learning and Verbal Behavior, 21, 150-164.

Schlenck, K. J., Huber, W., \& Willmes, K. (1987). “Prepairs” and repairs: different monitoring functions in aphasic language production. Brain and Language, 30, 226-244.

Song, M. J. (1995). Developmental psychology. Seoul: Hakjisa.

Vasta, R., Haith, M. M., \& Miller, S. A. (1992). Child psychology: the modern science. New York, NY: John Wiley \& Sons.

Vygotsky, L. S. (1962). Thought and language. Cambridge, MA: MIT Press.

Won, S. Y. (1998). A study of the effect on the short-term memory capacity of the mild mentally retarded children by rehearsal patterns and condition of assignment presentation (Master's thesis). Daegu University, Gyeongsan, Korea. 
Appendix 1. 비단어따라말하기 목록

\begin{tabular}{rlll}
\hline 문항 & A세트 & B세트 & C세트 \\
\hline 1 & 디다삥 & 너눙닉 & 더눌렁 \\
2 & 레겐넉 & 느롱엘 & 드넨넵 \\
3 & 레을룽 & 데릅뜹 & 머겜밍 \\
4 & 네름딕 & 느람블 & 흐넬맏 \\
5 & 버론둥 & 니버껑 & 따깅읃 \\
6 & 후도벵걱 & 거그툰닌 & 뻬응믄돔 \\
7 & 모머랑깅 & 버딤네둡 & 니덩멜렙 \\
8 & 두빌두덩 & 더렝겡멘 & 두넘몽뎅 \\
9 & 무멘기딜 & 꾸머큰넥 & 뿌른번눕 \\
10 & 하든고닙 & 뜨내벤닐 & 떠베띵님 \\
11 & 라겡더엄벵 & 너멜렘두넥 & 그렝뎀꾸겝 \\
12 & 허너렝벨룬 & 버님머넨덱 & 느렌두멀릅 \\
13 & 리뭉버널림 & 뽀넘므텍뜹 & 뻬드믈레넴 \\
14 & 므랑느붐멘 & 드메너쁜눔 & 삐딤두밍닐 \\
15 & 데더루몰룽 & 두레뻬뚤뎁 & 두멤네넨받 \\
\hline
\end{tabular}




\section{국문초록}

\section{6,7 세 아동의 시연조건에 따른 지연 비단어따라말하기 능력 비교}

이석정 1 하지완 ${ }^{12,3} \cdot$ 구민모 ${ }^{4}$ 황유미 3.5 편성범6,7

${ }^{1}$ 대구대학교 재활과학대학원 언어치료학과, ${ }^{2}$ 대구대학교 언어치료학과, ${ }^{3}$ 대구대학교 국제재활과학연구소, ${ }^{4}$ 고려대학교 안암병원 의생명연구센터, ${ }^{5}$ 고려대학교 언어정보연구소, ${ }^{6}$ 고려대학교 의과대학 재활의학교실, ${ }^{7}$ 고려대학교 안암병원 융합뇌신경연구센터

배경 및 목적: 외현적 시연, 내현적 시연, 시연 억제의 상이한 시연조건들이 아동의 음운단기기억에 어떠한 영향을 미치는지 알아보기 위해, 시연조건에 따른 지연 비단어따라말하기 수행력을 분석하고 말지각, 단기기억, 어휘량과 그 수행력과의 관계를 분석하였다. 방법: 6,7 세 일반아동 20 명씩을 대상으로 외현적 시연, 내현적 시연, 시연 억제 조건에서 지연 비단어따라말하기 과제를 실시하여, 정확도와 오류유형 분석을 실시하였다. 자음변별검사, 숫자 바로따라하기 검사, 표현어휘량을 측정하여, 변인들 간 상관관계와 따라말하기 정확 도에 대한 예측변인을 분석하였다. 결과: 6세 집단은 외현적 시연, 내현적 시연, 시연 억제 순으로 높은 수행력을 나타낸 반면, 7세 집단 은 외현적 시연과 내현적 시연 간 유의한 차이가 없었고 두 조건과 시연 억제에서만 차이를 보였다. 6 세 집단은 시연 억제에서 무반응 오 류를 가장 많이 보였지만, 외현적과 내현적 시연에서는 음소대치 오류가 증가하였다. 7세 집단은 모든 시연조건에서 음소대치를 가장 많 이 보였다. 말지각, 단기기억, 표현어휘량은 모든 시연조건의 수행력과 상관이 유의하게 높거나 있었다. 외현적 시연에서는 숫자 바로따 라하기, 내현적 시연에서는 자음변별, 시연 억제에서는 자음변별과 표현어휘량이 예측변인으로 분석되었다. 논의 및 결론: 시연활동은 아동의 음운단기기억에 긍정적 영향을 미친다는 것을 확인하였다. 그러나 연령에 따라 외현적 시연과 내현적 시연의 효과가 다르게 나 타나므로, 음운단기기억 향상을 위해서는 연령별 다른 시연전략을 적용하여야 한다.

핵심어: 지연 비단어따라말하기, 외현적 시연, 내현적 시연, 시연 억제, 음운단기기억

이 논문은 2013년 정부(교육부)의 재원으로 한국연구재단의 지원을 받아 수행된 연구임(NRF-2013S1A3A2043454).

이 논문은 2014년도 대구대학교 연구장학기금 지원에 의한 것임.

\section{참고문헌}

곽금주, 오상우, 김청택(2011). K-WISC-IV 전문가 지침서. 서울: 학지사.

권미선(2004). 베르니케실어증 환자의 실어유형 및 청각언어이해능력의 변화 특성. 이화여자대학교대학원 박사학위논문.

김나연, 하지완(2014). 조음음운장애아동과 일반아동의 음운표상의 질과 음운표상 부호화 능력 비교. 언어청각장애연구, 19, 225-237.

김영근(2012). 기억전략이 회상기억에 미치는 영향과 작업치료 함의: 범주화와 시연전략 중심으로. 대한인지재활학회지, 1, 5-21.

김영태, 신문자(2004). 우리말 조음음운평가(U-TAP). 서울: 학지사.

김영태, 홍경훈, 김경희, 장혜성, 이주연(2009). 수용·표현어휘력검사(REVT). 서울: 서울장애인복지관.

김옥향(1997). 언어적 시연과제에서 연속 및 휴지조건이 회상기억에 미치는 효과. 유아교육학논집, 1, 239-262.

김지윤(1988). 아동기억에 있어서 범주적 조직의 사용에 관한 연구. 이화여자대학교대학원 석사학위논문.

김효정, 최선영, 하지완(2015). 아동기 말실행증, 조음·음운 장애 및 일반 아동의 말-운동프로그래/프로그래밍 능력 비교. 언어청각장애연구, 20, 60-

71.

김흥규, 강범모(1997). 한글 사용빈도의 분석. 서울: 고려대학교 민족문화연구원.

문선모(1994). 학습방략의 발달과 학업수행. 교육학연구, 32, 47-74.

박영아(2007). 아동의 기억책략사용에서의 이용결여 현상과 메타기억의 영향. 성균관대학교대학원 박사학위논문.

백수진, 안성우, 서유경, 신영주(2007). 읽기장애아동과 일반아동의 작업기억 특성 비교 연구. 정서·행동장애연구, 23, 265-300. 
송명자(1995). 발달심리학. 서울: 학지사.

원상연(1998). 시연유형과 과제제시 조건이 경도 정신지체아의 단기기억 용량에 미치는 효과. 대구대학교대학원 석사학위논문.

이대훈(2015). 정상 성인의 연령에 따른 즉각 음운 단기기억과 지연 음운 단기기억 수행력. 대구대학교대학원 석사학위논문.

이현정(2010). 음절길이와 단어유사성이 3-5세 한국어-영어 이중언어아동의 비단어따라말하기 수행에 미치는 영향. 이화여자대학교대학원 석사학 위논문.

정용석(2012). 조음억제행동의 조작이작업기억체계의 수행에 미치는 영향. 서울대학교대학원 박사학위논문.

정용석, 김정오(2010). 즉시순차기억에서의 조음억제: 외현적 조음억제는 음성하 시연을 차단하는가? 한국심리학회지: 인지 및 생물, 22, 311-335.

조남호(2002). 현대 한국어 사용 빈도. 서울: 국립국어연구원.

황민아(2015). 일반아동의 비단어 따라말하기. 언어청각장애연구, 20, 374-385. 